\title{
Education Facing Globalization in Post-communist Country: Azerbaijan
}

\section{Isaxanli, Hamlet}

Department of Education, Khazar University, Azerbaijan.

\begin{abstract}
Contemporary education, especially, the development of higher education is tightly bound with globalization and is also one of those indications characterizing the globalization. The impact of globalization on higher education is very wide and complex in post-communist countries. This research paper looks at the main characteristics of globalization as a whole, its influences on post-Soviet societies: the refusal and acceptance of the trends brought by globalization in post-communist countries, its impacts on education systems of less developed and developing countries, import of features of long-established education systems from abroad. The weaker education systems' vulnerability before those powerful, well-established and long-standing education systems and the hard competition conditions encountered by them have been touched upon in this article. Subsequently, Azerbaijan, the pathways of its education history beginning from Russian Empire and Soviet Union, the language and alphabet changes, and aftermath the modern education system of Azerbaijan, newly established universities such as Khazar University, their local and international achievements and challenges and the overall situation of higher education in the country have been discussed as the case study.
\end{abstract}

Key-words: globalization, higher education, post-communist country, Azerbaijan, Khazar University. 


\section{What is Globalization?}

Globalization is the integration process in the world. It is the increase of communication in high degree, unification and compaction or "diminution" process of the world, the activity of humans of delivering their 'hand' or thoughts to the world. Globalization is openness, vast augmentation of political and cultural influences, and getting across the national borders. Globalization is internationalization of competition. Globalization is acting in the world market and it is beyond the power of the states. Globalization is standardization of main services, growth in migration, turning the science, technology, information and higher education to be world network, as well as severely worsening of energy, climate change and other environmental problems. Networking (including making ground of narcotics and terrorism), strengthening of cooperation and mutual dependence have become the driving force of modern globalization. That's where the contradiction appears and deepens between modernism which is derived from globalization and society's tradition system, as well as between generations.

Extraordinary amplification of the means of transport and communication played an important role in becoming of globalization the main trend of the time. As the consequence of globalization, the acceleration of time comes to agenda, that's to say, big changes happen within a short time, the distances get shorter or fade out, it means instant virtual contact and travelling the long distances with high speed. Only in two or three decades, thanks to the technologies like internet and mobile phone, the power of international communication made a giant leap.

The power of the English language increased fantastically as the result of globalization, it turned to be lingua franca of the world. English became, in fact, a tool and sign of globalization. Globalization raised the number of people speaking two or more languages.

Critics of globalization consider that the globalization process empowers those who have more powerful political, technological and financial opulence; creates conditions for stronger ones to exploit the weaker ones; damages the spiritual values and social norms, traditions, and inherent collective identity of so-called weak countries. Educated and competent people leave their own countries and head to more developed ones, in other words, brain drain takes place.

The collapse of traditional socialism, spread of market economy, and expansion of democratic movements approximately overlapped; in fact, these are the events, related to one another. The idea of supplying the varying demands of people not by private initiatives and private investment, but by the state planning got failed. The Soviet Union could not find the solution of this problem and collapsed, on the contrary, China improved the existing governing method without breaking it and applied the market economy, and grew stronger. Though, the expansion of democratic principles is one of the elements of globalization, the West tries to implement it by the same ways everywhere, without taking into account the historical 
developments and local culture and traditions; consequently, it takes to overwhelming civil wars, external interventions, and terror (for instance, Afghanistan, Iraq, Libya).

\subsection{Globalization in Higher Education}

In most countries, especially in small, also in less developed and developing countries, there is almost no national education system (especially, higher education); even though they don't express it openly, they are integrated to one of the long-established education systems. The states holding certain geographical, economical and ideological bounds prefer to gain "harmonization" in the substantial components of education, to build a unified education system or to bring educational systems closer to one another (or to a mutually acclaimed model), instead of protecting their distinctive education system. The Bologna Process is a bright example of this. The spread of European education system to the globe is a striking manifestation of globalization and modernization process of the world.

While the world has been globalizing, the numbers of students going abroad to study, as well as the numbers of teachers and men of science changing their places and countries have grown bigger. Distance education has become more appealing through the internet and other technologies. Transnational companies employ university graduates in distinct countries. Amplification of these opportunities sets the mission upon the universities on nurturing global citizens, which, in its turn, might have a negative impact on the development of local cultural identity.

Globalization confronts the academic culture with the market or corporate culture. Academic culture is firmly established and tends to change slowly. Yet, technology and lifestyle change more rapidly, and neither it can be neglected, nor not taken into proper consideration. In contemporary times, the university is required to incorporate entrepreneurial elements into academic culture, and pursue a company-type financial policy (Weber and Duderstadt, 2008).

Worldwide spread of private universities is also appearance of globalization (Altbach and Levy, 2005), though post-communist countries also show lameness in this context. The main reason to this is the fact, that most of the public universities in these countries are inefficient, inflexible, resilient against changes, and cannot adjust themselves to globalization.

Beginning from 2003, the Global Ranking of the Universities were launched (particularly, Jiao Tong University - Shanghai, THES = Times Higher Education Supplement and QS). The rankings have the greatest focus on scientific research, but it is difficult to properly identify the quality of education; it can be done partly through certain statistical information. This competition, this race has gained a great popularity, as in sport. Different countries set as their goals to include own universities to the list of World Class 
Universities or to increase their number, and some countries established pertinent plans to achieve their aims. The existence of too much competition, the long-standing success and reluctance to significant decline of the majority of the popular universities, complicate the inclusion of young universities into the well-known universities list. The combination of qualities such as proper funding, rightful state policy and strive for creativity and management culture are essential.

Marx (and the Marxists) considered the transition to socialism by overthrowing of capitalism, as the way to eliminate the inequality, inherent to capitalism. Socialism, which achieved relative equality, also largely restricted human freedom. However, historical experience has shown that human freedom is related to a free economy, that is, capitalism. People of post-communist countries in the transition period tasted the bitterness and sweetness of both experiences. The society and individuals were delighted with freedom, but felt dismay because of inequality. The way to weaken and reduce inequality, first of all, is possible through education; education creates relatively equal opportunities! For getting admission to a better university, the child of poor family gains the upper hand over the child of rich family by demonstrating good knowledge. This is the great value of education!

\subsection{Azerbaijan}

There are two territories named Azerbaijan. The first is the Republic of Azerbaijan. The second includes the North-Western provinces of Iran, the names of which contain the word Azerbaijan. The populations of both places speak mostly the same language - Azerbaijani, or Azeri, or the Azerbaijani Turkic language. The population of the Republic of Azerbaijan is close to 10 million. Nobody knows the exact number of Iranian Azerbaijanis, but there are estimations of 17 to 27 million.

As a result of wars between Russia and Iran from 1796 till 1828, Russia occupied the Caucasus and the Azerbaijani people were divided. The Northern part (Caucasus) passed to Russia, while the Southern part remained in Iran. From that time onwards, the two Azerbaijans followed different paths, although the connections between them were not totally lost. After the 1917 Revolution in Russia, the independent Azerbaijan Democratic Republic, the first Azerbaijan Republic, was established (May 28, 1918 - April 28, 1920) which then was incorporated into the Soviet Union as the second Azerbaijan Republic (1920/22 - October 18, 1991). Azerbaijan regained its independence as the result of the collapse of the USSR and became the third Azerbaijan Republic (since October 18, 1991). 


\subsection{On History of Education in Azerbaijan}

The entire $19^{\text {th }}$ century and beginning of the $20^{\text {th }}$ century may be considered as a colorful era of new search and novelty for education in Azerbaijan, which became a part of the Russian empire. Alongside the traditional religious schools, a network of secular schools was growing, and Russian-Azerbaijani ("Rus - Tatar") schools were increasing in number and gaining good reputation. Schools functioning entirely in the native language were also being formed by well-known educators, poets, and writers. Azerbaijanis went to the cities of Russia and Europe (Germany, France, Belgium, Poland...) to obtain higher education in various fields. During the First Azerbaijan Republic, Baku State University, the first European-Russian type university was founded and up to 100 young people were sent to higher education institutions of Europe.

The Second Azerbaijan Soviet Republic, replaced the Arabic script with a Latin-based alphabet (1924 to 1939). The anti-illiteracy campaign of this era must be noted. In 1939 the literacy rate in Azerbaijan was 82.8\% (men-88.8\%, women-76.1\%); In the 1960's, the literacy rate was practically $100 \%$. The universal compulsory education was implemented step by step. On January 1, 1940, the Latin alphabet was replaced with the Cyrillic alphabet. Administration of higher education was directly linked to Moscow. Only in 1959, when the slogan "Complete and Final Victory of Socialism" was announced (socialism would collapse 30 years after its "complete and final victory"), the Azerbaijani Ministry of Pre-Higher Education changed into the Azerbaijani School and Higher Education Ministry, thus, some kind of decentralization was introduced. Even though control of higher education institutions was given to Azerbaijan, the creation of new higher education institutions still depended on permission from Moscow.

It was possible to earn high school and higher education in one of two languages in Azerbaijan: Azerbaijani or Russian (the number of students studying in Azerbaijani was higher).

\section{Modern Age Higher Education in Post-communist country: Azerbaijan}

\subsection{New Type of University}

The decline of the Soviet Union and the political and economic downfall resulted in a great crisis in the fields of research, education and technology, which had already been falling behind. Corruption was widespread not avoiding education system. During the last academic year of the collapse of the Soviet Union (1990-1991), a new university with a new form and new substance was in the process of being founded. This was Azerbaijan's first private university, which would soon be named Khazar University (Khazar means Caspian). What were the goals of founding this university? 1) to create curricula and course 
programs like those of the leading universities of North America and Western Europe, 2) to use a student-centered, credit-based education model that would give students an opportunity to choose their own trajectory, 3) to be an institution with academic freedom, 4) to develop broad international environment and partnership programs, 5) to merge national and international human values, 6) to implement three-level Western type education with bachelors, masters and $\mathrm{PhD}$ programs, 7) to become a cultural center in addition to being an academic and research institution, 8) to develop university-industry relations, 9) to choose English as the main language of instruction (to facilitate student and instructor exchanges as well as the usage of cutting-edge class materials and textbooks), 10) to veto corruption (Isaxanli, 2006a).

Khazar University created a new path for itself and for Azerbaijani education. It paved this road and established a new university culture.

\subsection{Education Law}

In 1992, the Azerbaijani Parliament passed the Education Law, which contained many of the principles, that Khazar University was already promoting. The new Azerbaijani government also replaced the Cyrillic alphabet with a Latin-based alphabet.

In 2005, Azerbaijan joined the Bologna Process for higher education. Khazar University played a leading role in understanding this process and organizing related trainings. Unfortunately, a new Education Law, passed in 2009, did not pave the way for hope or reform, nor did it lead to progress in administration and management of education institutions; the phrase often repeated in this legislation, "determined by the respective executive authority," does not say anything serious from a legal perspective. The new education law solved the problem of academic degrees by borrowing both from Western and from Soviet models; a four-level degree system was introduced including bachelor, master, $\mathrm{PhD}$ and Doctor of Science (in which the $\mathrm{PhD}$ degree stands for Doctor of Philosophy, saying, for example, "Doctor of Philosophy in Chemistry" or "Doctor of Philosophy in History").

\subsection{Governance}

The autonomy of higher education institutions in Azerbaijan leaves much to be desired. Even private institutions do not have freedom in admission of students, in starting new academic programs, or in giving diplomas to graduates. This creates difficulties for the institutions in working on and implementing action plans or strategic development plans. Government is mostly, defender of status quo, rather than initiator of a reform. At the same 
time, certain controlling government policy in terms of accountability of higher education institutions and social protection of employees is comprehensible.

The rectors of state higher education institutions are appointed and removed by order of the President of the Country, and the vice-rectors are also practically chosen "from above". There is no such thing as a Board of Governance, Board of Directors or Board of Trustees in these institutions. Khazar University is an exception; it has applied an administrative model close to a synthesis of collegial consensus and a polycentric model.

There is no "buffer" between the internal and external worlds of higher education institutions, no role in leadership and administration for stakeholders. There are no real and well-established Alumni Organizations. Without Board of Trustees (Governance, Directors) it is always impossible to formulate mission statement and strategic development plan of the institution, to provide political leadership, and search for key leadership. Rector`s duties with both managerial and political activity, double leadership is not right and effective way. The Academic and Administrative Councils (Senates) not only do not share the rector's power, but they even facilitate the rector's ability to abuse and manipulate his/her authority. It is said that the presidents of American colleges and universities have more authority than their European counterparts (Trow, 1994). In general, American universities enjoy the extraordinary power in its full meaning (Kerr, 2001). In my opinion, Azerbaijani rectors are more powerful than the American ones (not in the sense of effectiveness or excellence, but simply with regards to their authority). But, at the same time, rector of public university can be fired any time by the President of Azerbaijan, without preliminary notification.

When higher education institutions were founded in Azerbaijan in the 1920s, they did not have their own scholars, like in America's colonial period, which probably necessitated responsible and authoritative rectors. The obligation to serve the ideology of the time also increased the rectors' responsibility and areas of control. Rectors of Azerbaijani higher education institutions can completely interfere with the activities of academic departments and the selection of instructors, and this is not always done for quality assurance (an American university president does this in very exceptional cases, such as "putting into receivership", see, Trow, 1994, pp. 280-281).

There are no independent accreditation agencies in Azerbaijan; and it does not allow for objective observation that would help solve central problems such as increasing the quality of education. There is no link between the level of quality in education and state funding. Instructor salaries are categorically insufficient, but, some improvement at some universities may be observed in recent years (Guliyev, 2018; Isaxanli, 2006b; Isaxanli, 2014). 


\subsection{Research, PhD Programs and Academy of Science}

One of the most concerning problems is that $\mathrm{PhD}$ programs and academic research in higher education institutions are not suitably developed. The $\mathrm{PhD}$ and Doctor of Science degree-awarding process has been preserved as it was in Soviet times. Because of this archaic system, fixed Academic Defense Councils were established in different institutions for different academic fields (in higher education institutions and in the Academy of Sciences), and the defenses of dissertations take place only before those Councils. Each council usually have 25 permanent members, as a rule, those who understand the topic being defended and are specialists of the relevant field make up minority, so majority council members vote without any understanding of the research. Dissertations that have been defended and related documents are sent to an organization called the Supreme Attestation Commission, where they are evaluated and approved. Experience shows that this bureaucratic system does not breed quality, just contrary, creates way to bribery.

It is necessary to take extraordinary long and wearisome steps before the dissertation defense. Confirmation of topics in centralized councils, conducting examinations in centralized places (for example, candidate for a degree of the higher education institute, which is much stronger in computing sciences, should go to the Academy's Institutional Examination ...). After the dissertation defense, a disruptive Supreme Attestation Commission steps out. Some people go through this system by pulling strings or giving bribes, others must wait for six months, one year, one and a half year to approve their degrees. While higher education facilities confer thousands of bachelor's and master's degrees, extraordinary, unnatural and inefficient system continues to function instead of $\mathrm{PhD}$ and higher scientific degrees being awarded by universities, based on accurate assessment of 5-6 specialists. The Baltic states and Georgia in this issue have also switched to a rapidly developing world model.

Material basis (buildings, number of employee, ...) of the Azerbaijan Academy of Sciences is bigger than cumulative material basis of four well-known academies (Royal Society, UK; Académie des sciences, France; National Academy of Sciences, USA; Leopoldina Academy of Germany). However, Azerbaijan Academy of Sciences is quite weak in terms of scientific research. Majority of employees are old and unproductive. Young and talented persons do not go to the Academy. The issues like vastitude and covertness of Soviet system, planned economy peculiar to socialism, and employment for everybody provided by the state, divided the science and education into three units: higher education system, academy of sciences consisting of a network of research institutions, and field institutions related to industry, ministries and distinct committees. Alas, encompassing the Academy of Sciences in this system serious reforms have not been enforced. 
In recent years some positive steps have been taken that are worth noting: higher education institutions have been given exemption from value-added taxes; relatively good quality private universities have been able to obtain merit-based state scholarships for students (these scholarships are much less than the tuition fees for private institutions); The National Science Foundation conducts activities, to assist scientific research; and attention is paid to construction and renovation activity for educational institutions. Unfortunately, there is no place yet in this list for an effective student loan system. Instead of the process of reunification and strengthening of universities and research institutes in Azerbaijan, the process of fragmentation, disintegration and multiplication of universities persistently goes on. This rather reduces its effectiveness and capacity.

\section{Conclusion}

Globalization being a major trend in modern days, has a significant impact on all aspects of life, including the education system. Less or not highly developed countries are compelled to go in the same pathway as the firmly established countries, and make changes in that direction, either voluntarily or constrainedly. Post-communist countries are striving to resolve the dilemma of complete imitation or synthesis, deliberating between life style, dictated by legacy and globalization.

Azerbaijan, formerly, was set to establish European-Russian type educational institutions within the Russian Empire, in 1918-1920, during the First Republic, embarked steps towards higher education, and during the Second Republic, in other words, in Soviet Era, acquired education system intrinsic to Socialism. During the new independent Third Azerbaijan Republic (since October 18, 1991), several trends appeared in the education system: creation of a flexible private higher education system that suggested new content and forms, endeavours made to keep up with a global educational movement like the Bologna Process and implementation of the appropriate reforms in the education system.

Although a number of positive changes have taken place, the content of education as a whole, the governance of education, development of system with regards to scientific research and high academic degrees are not adequate and satisfactory, thus, there is a need to establish research-education system that would pertain to worldwide trends and could give an impetus towards economic, technological, and cultural development of the country. 


\section{References}

Altbach, P. G., and Levy, D. C. (eds.) (2005) Private Higher Education: A Global Revolution. Rotterdam: Sense Publishers.

Guliyev, F. (2018) 'The Enigmatic Connection Between Education and Civic Apathy in Azerbaijan'. PONARS Eurasia Policy Memo No. 519, March 2018. Elliot School of International Affairs, The George Washington University.

Isaxanli, H. (2006a) In Search of “Khazar”. Baku: Khazar University Press.

Isaxanli, H. (2006b) On Education System in Transition Economy. A View from Azerbaijan. Baku: Khazar University Press.

Isaxanli, H. (2014) 'Diversification of post-secondary education in Azerbaijan' In Varghese, N.V. The diversification of post-secondary education, pp. 45-58. UNESCO, International Institute for Educational Planning.

Kerr, C. (2011) The Uses of the University. Harvard University Press.

Trow, M. (1994) 'Comparative Reflections on Leadership in Higher Education' In Altbach, P. G., Berdahl, R. O. and Gumport, P. J. (eds.) Higher Education in American Society, pp. 269-288. New York: Prometheus Books.

Weber, L. E. and Duderstadt J. J. (eds) (2008) The Globalization of Higher Education. London: Economica. 